\title{
Cultura Cultura
}

\section{Fontes para a iconografia teresiana no convento do Santíssimo Coração de Jesus à Estrela}

Theresian Iconography on the convent of the Holy Heart of Jesus in Lisbon

\section{Sandra Costa Saldanha}

\section{(2) OpenEdition}

\section{Journals}

\section{Edição electrónica}

URL: http://journals.openedition.org/cultura/3041

DOI: $10.4000 /$ cultura.3041

ISSN: 2183-2021

\section{Editora}

Centro de História da Cultura

\section{Edição impressa}

Data de publição: 1 Janeiro 2005

Paginação: 101-126

ISSN: 0870-4546

\section{Refêrencia eletrónica}

Sandra Costa Saldanha, «Fontes para a iconografia teresiana no convento do Santíssimo Coração de Jesus à Estrela », Cultura [Online], vol. 21 | 2005, posto online no dia 02 junho 2016, consultado a 01 maio 2019. URL : http://journals.openedition.org/cultura/3041 ; DOI : 10.4000/cultura.3041

Este documento foi criado de forma automática no dia 1 Maio 2019.

(c) CHAM - Centro de Humanidades / Centre for the Humanities 


\section{Fontes para a iconografia teresiana no convento do Santíssimo Coração de Jesus à Estrela}

Theresian Iconography on the convent of the Holy Heart of Jesus in Lisbon

Sandra Costa Saldanha

O antigo convento carmelita do Santíssimo Coração de Jesus à Estrela encerra um interessante conjunto de painéis de azulejos alusivos à vida de Santa Teresa de Jesus, cujas composições foram concebidas a partir da cópia directa de dez gravuras do álbum Vita S. Virginis Teresiae a Iesv. 

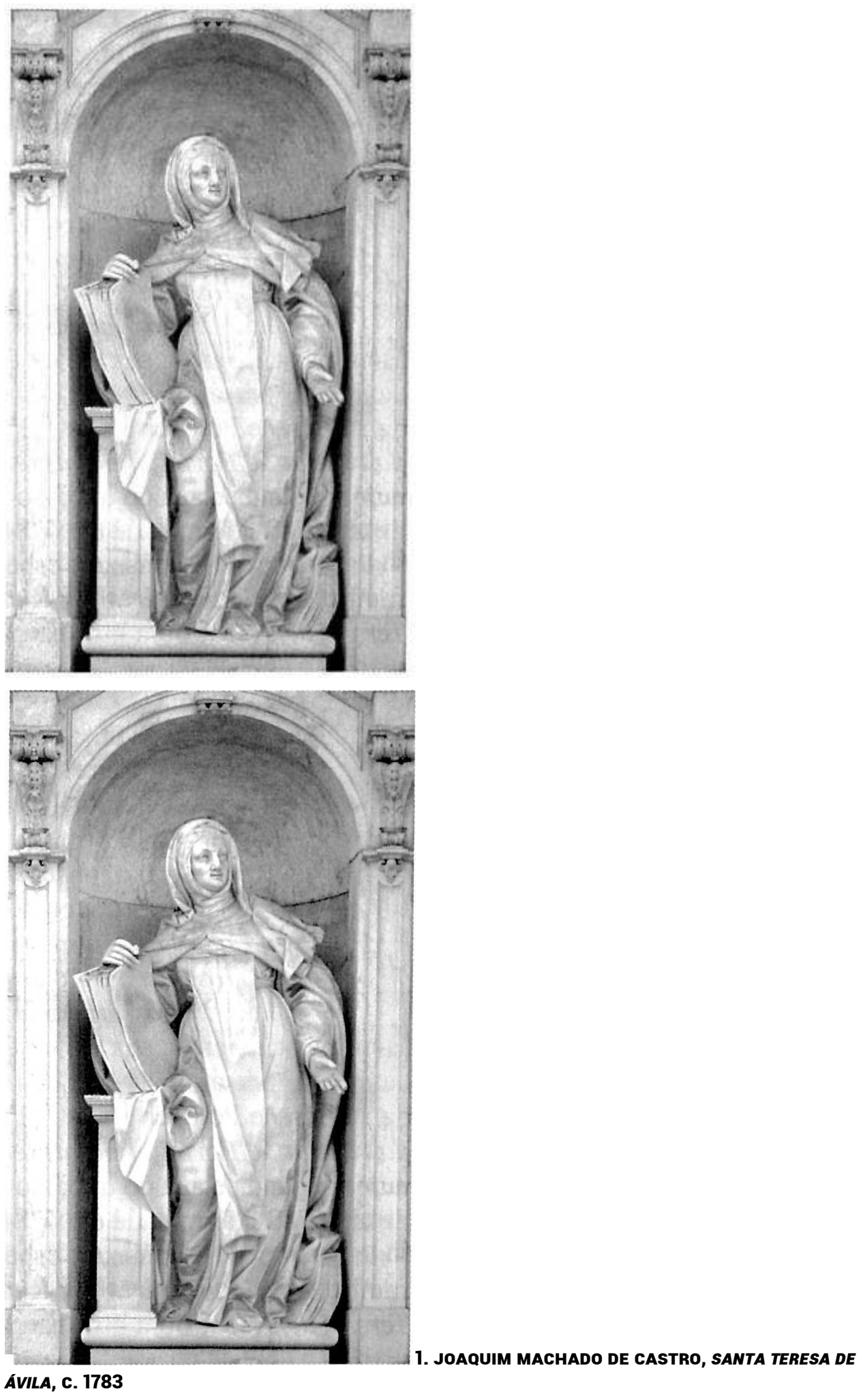

Obra integrada na iconografia geral do edifício, os principais assuntos ilustrados no complexo dividem-se, basicamente, em quatro tipos: temática alusiva à Ordem Carmelita, onde se incluem sobretudo passos da vida de Teresa de Ávila; temas relacionados com a devoção e encomenda do templo e convento, com representações da rainha, do Santíssimo Coração de Jesus e de religiosos carmelitas; e outros assuntos de cariz 
religioso, onde se integram temas que não cabem no propósito essencial da construção, como cenas da vida de Cristo, da Virgem e de outros santos. ${ }^{1}$

Quanto às principais representações de Santa Teresa, merece destaque especial a composição escultórica da fachada da basílica, executada por dois dos ajudantes de Joaquim Machado de Castro (1731-1822), Alexandre Gomes e João José Elveni. Obra integrada no programa iconográfico inicial do templo, que contemplava alguns dos principais santos carmelitas, ${ }^{2}$ Teresa de Jesus surgia no modelo original representada com três livros, símbolo da sua condição de escritora, reformadora e doutora da igreja.

Em termos compositivos, é sintomático reconhecer que a obra se filia na célebre escultura com o mesmo tema do florentino Filipo della Valle (1697-1768). Colocada num dos nichos da nave da basílica de São Pedro, um anjo semi-nu acompanha a Santa, segurando nas mãos um dardo e o coração em chamas, alusivos à célebre passagem biográfica da Transverberação. Colaborando na realização da série de estátuas de santos fundadores de ordens religiosas, a importância do projecto do Vaticano, que Della Valle concluiu em 1754, assim como o factor propagandístico que lhe estava inerente, favoreceu naturalmente a divulgação de tais obras. Como era frequente em empreendimentos de vulto, também a imagem dessa estátua seria gravada, pelo italiano Silvio Pomarede (act. 1736-1768), conservando-se um exemplar no convento feminino de carmelitas da cidade espanhola de Valladolid. ${ }^{3}$

$\mathrm{Na}$ basílica da Estrela, o espaço onde se encontra o maior conjunto de representações de Santa Teresa de Ávila é o antecoro da igreja. Com um programa iconográfico bastante coerente, subordinado a temas da vida da Reformadora do Carmo, observa-se, ao nível do tecto, a Transverberação e, nas paredes, seis telas com passos da sua vida, a saber: Santa Teresa com São Pedro e São Paulo, Esponsais místicos, Santa Teresa fundadora acompanhada por dois anjos, Imposição do colar e Santa Teresa perante o Ecce Homo. ${ }^{4}$

Paralelamente, a especificidade do convento da Estrela, nomeadamente as circunstâncias da sua encomenda e construção, determinaram a execução de obras especialmente adequadas ao edifício. É disso exemplo uma das obras da autoria de Pompeo Batoni (1708-1787): Santa Teresa a receber as ofertas da rainha de Portugal na presença das freiras carmelitas, pintura integrada numa segunda etapa do trabalho deste artista romano para a Estrela, arrematada em 1782 e terminada em 1784.

No mesmo contexto, cabe ainda referir o tecto da denominada sala da rainha, com a figuração da Rainha doando os planos da Basilica a Santa Teresa de Jesus, obra atribuível a Cirilo Volkmar Machado (1748-1823), e integrável numa campanha decorativa que situámos nas últimas duas décadas do século XVIII. ${ }^{5}$

\section{Vita S. Virginis Teresiae a lesu - um livro em imagens}

Vita S. Virginis Teresiae a Iesu Ordinis Carmelitarum Excalceatorum Piae Restauratricis é o título de um conjunto de vinte e cinco estampas numeradas, editadas pela primeira vez em 1613 sob a forma de álbum, mas que podem também encontrar-se avulsas, agrupadas em séries ou integradas em livros. 


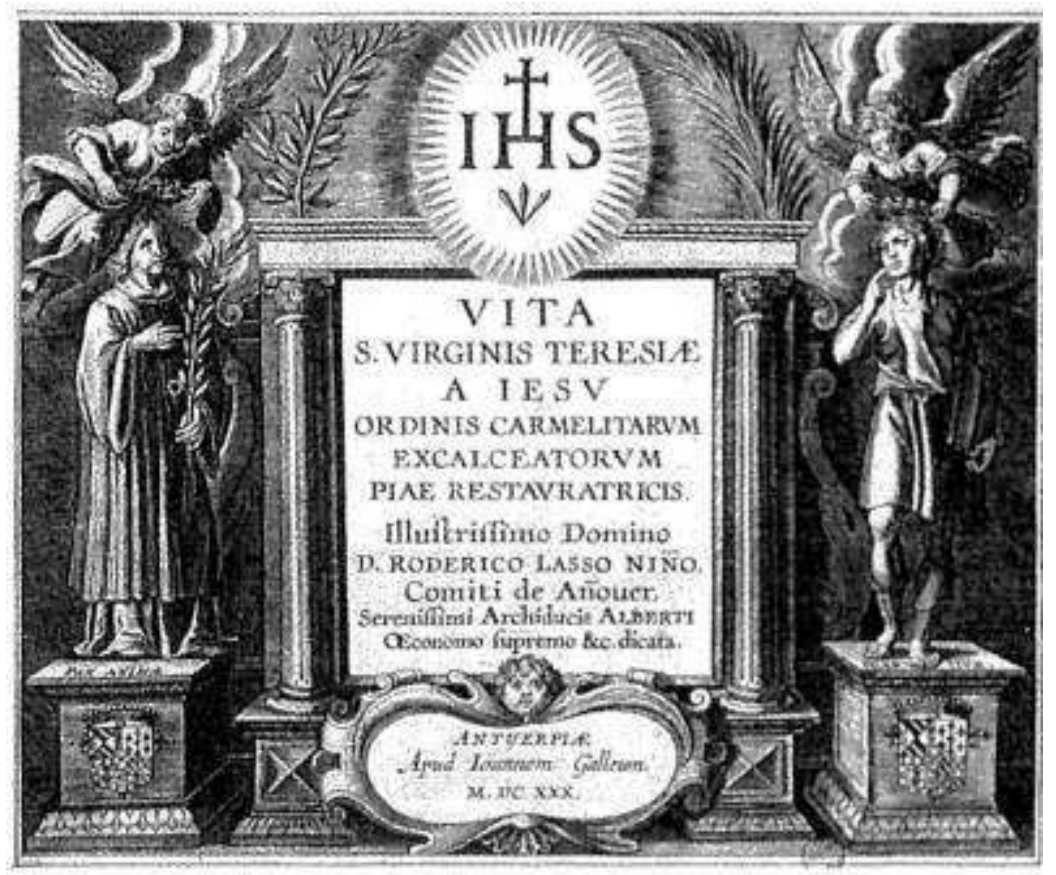

2. Portada de Vita S. Virginis Teresiae a lesu, 1630

A publicação da obra ficou a dever-se à iniciativa de madre Ana de Jesus (1545-1621), discípula de Santa Teresa que fez parte do grupo de religiosas que ingressaram no primeiro mosteiro da Reforma, o convento de São José em Ávila (1562). Conhecida por ter acompanhado a Santa em diversas das suas Fundações, foi também priora-fundadora dos conventos de Beas de Segura (1575), de Granada (1582), de Madrid (1586) e de Salamanca (1596). ${ }^{6} \mathrm{Em} 1604$, juntamente com Ana de São Bartolomeu (1549-1626), ${ }^{7}$ fundadora do mosteiro de Amberes, deslocou-se a França, onde inaugurou vários conventos e, posteriormente, à Flandres onde desde 1607 exerceu funções de priora, no Carmelo Real de Bruxelas.

Desempenhando um papel fundamental na divulgação da vida e da actividade de Teresa de Jesus, promoveu em França e na Flandres, por encargo do 


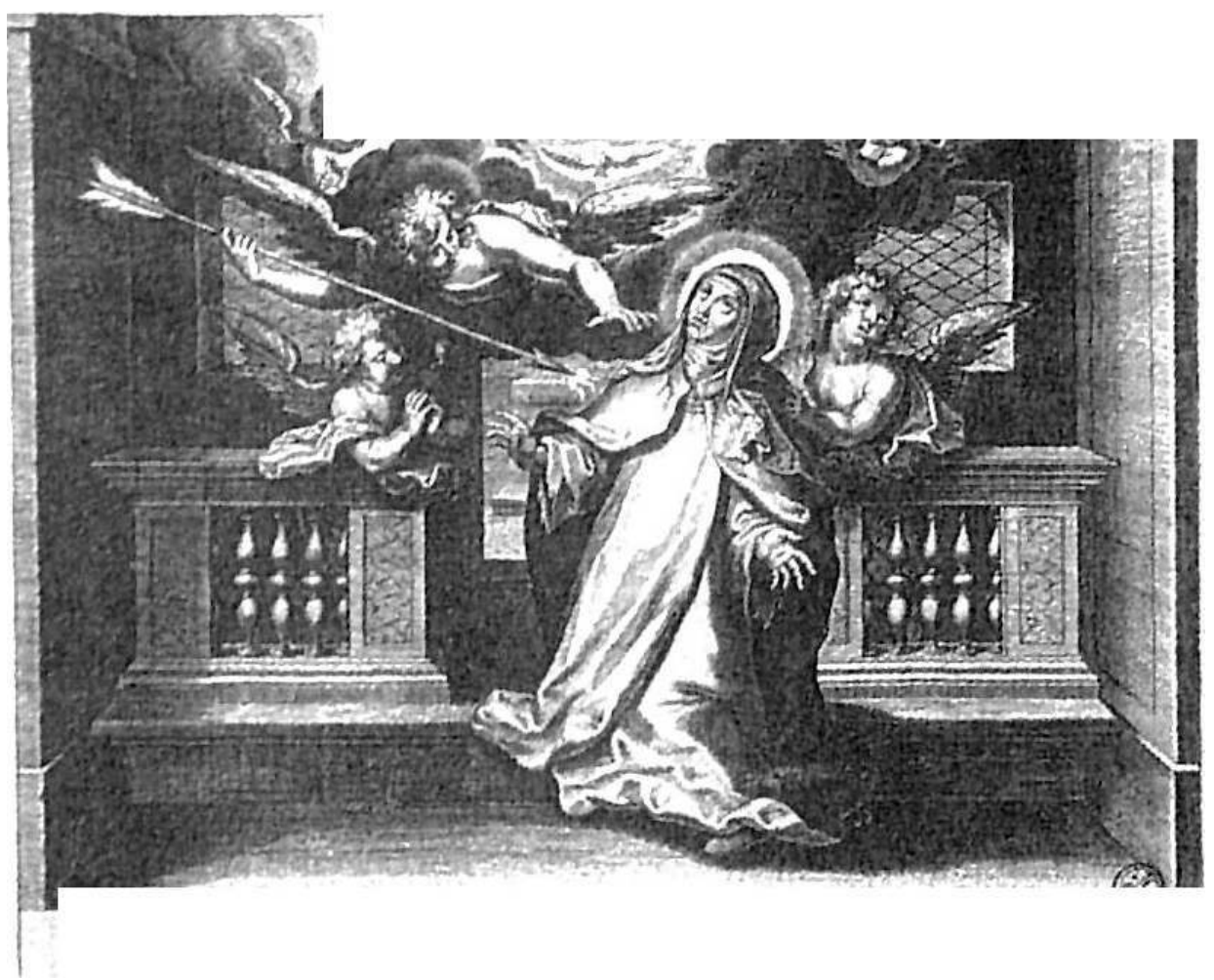

definitório geral da Ordem, a tradução para francês, flamengo e latim de algumas das suas obras.

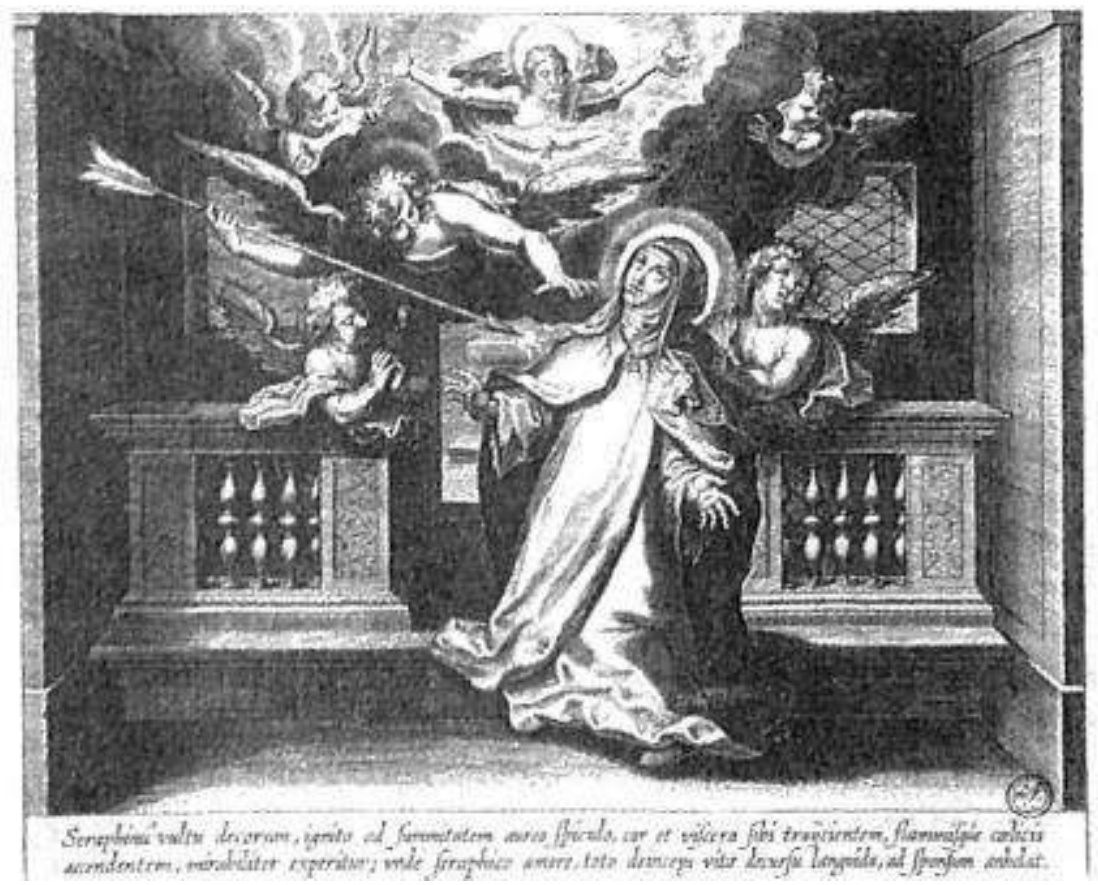

3. Transverberação de Santa Teresa

Aguardando a beatificação da Reformadora, Ana de Jesus foi também a responsável pela realização de uma série biográfica de estampas, representativas de uma parte da vida de Santa Teresa. A primeira edição foi impressa em Amberes, em 1613, e da sua realização foram incumbidos os gravadores Adriaen Collaert (1560-1618) e Cornelis Galle 
(1576-1650), autores consagrados pelas composições de reconhecida qualidade técnica, especialmente naquelas dedicadas à vida de santos. ${ }^{8}$

Editado em álbum nas vésperas da beatificação de Santa Teresa (1614), o conjunto de gravuras foi dedicada a D. Rodrigo Lasso Nino, conde de Hanover, ecónomo do arquiduque Alberto e marido da infanta Isabel Clara Eugénia, governadora dos Países Baixos e amiga de Ana de Jesus que, como vimos, foi a principal promotora da iniciativa.

Da série de 1613, conservam-se exemplares completos nos conventos femininos de São José, de Ávila e de Medina del Campo, assim como na secção de iconografia da Biblioteca Nacional de Madrid. ${ }^{9}$ Após a primeira edição, volta a ser publicada em Amberes uma segunda série, ainda nesse ano, e em 1630 uma terceira, da qual existe na Biblioteca Nacional de Lisboa um exemplar. ${ }^{10}$

Apesar da primeira série não ter sido superada tecnicamente por nenhuma das posteriores, são no entanto de assinalar ligeiras diferenças entre elas, subtilezas fundamentais dado que se confundem por diversas vezes, nomeadamente quando usadas para a análise iconográfica de obras de arte..$^{11}$ Mais recentemente, a obra de Collaert e Galle mereceu várias edições fac-símile, como é o caso das que foram publicadas em Montreui-Sur-Mer (1896), Gante (1929, com dupla edição em flamengo e francês) e Madrid (1914, no centenário da beatificação de Santa Teresa; e 1962, no centenário da Reforma da Ordem do Carmo).

\section{Os temas}

Certamente imbuída da atmosfera contra-reformista que se respirava então, coube a Ana de Jesus a responsabilidade de seleccionar os momentos biográficos que deveriam ser fixados pelos artistas de Amberes. Com o auxílio de Ana de São Bartolomeu, as duas religiosas basearam-se essencialmente no legado escrito de Teresa de Ávila, em especial no Livro da Vida e no Livro das Fundações.

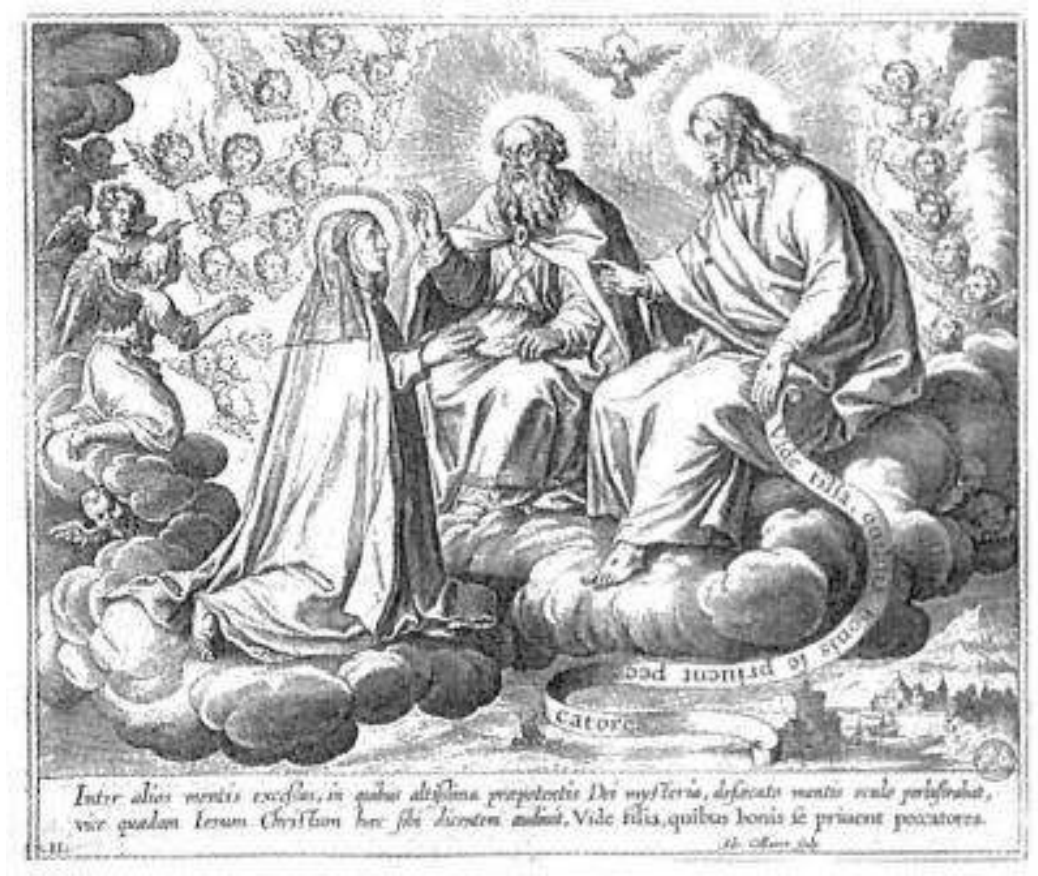

4. Santa Teresa perante a Trindade 
Apesar da conhecida vocação literária de Teresa de Jesus se ter manifestado precocemente, foi no decorrer da ampla actividade como fundadora que escreveu o maior número das suas obras, todas elas a instâncias dos seus superiores e directores espirituais. Estes livros, cujo âmbito era normalmente de carácter biográfico, conselhos, normas da vida espiritual e religiosa, acabariam por se converter em textos doutrinais.

No intuito de promover um sistema de pensamento, no seio dos conventos que ia fundando sob os princípios da sua Reforma, alguns desses escritos alicerçaram também os principais temas ilustrados nas gravuras de Antuérpia. Com efeito, a difusão da obra literária, sobretudo dos títulos de carácter biográfico e as descrições de experiências místicas contribuíram, logo após a canonização (1622), para a definição de uma parte significativa da sua iconografia.

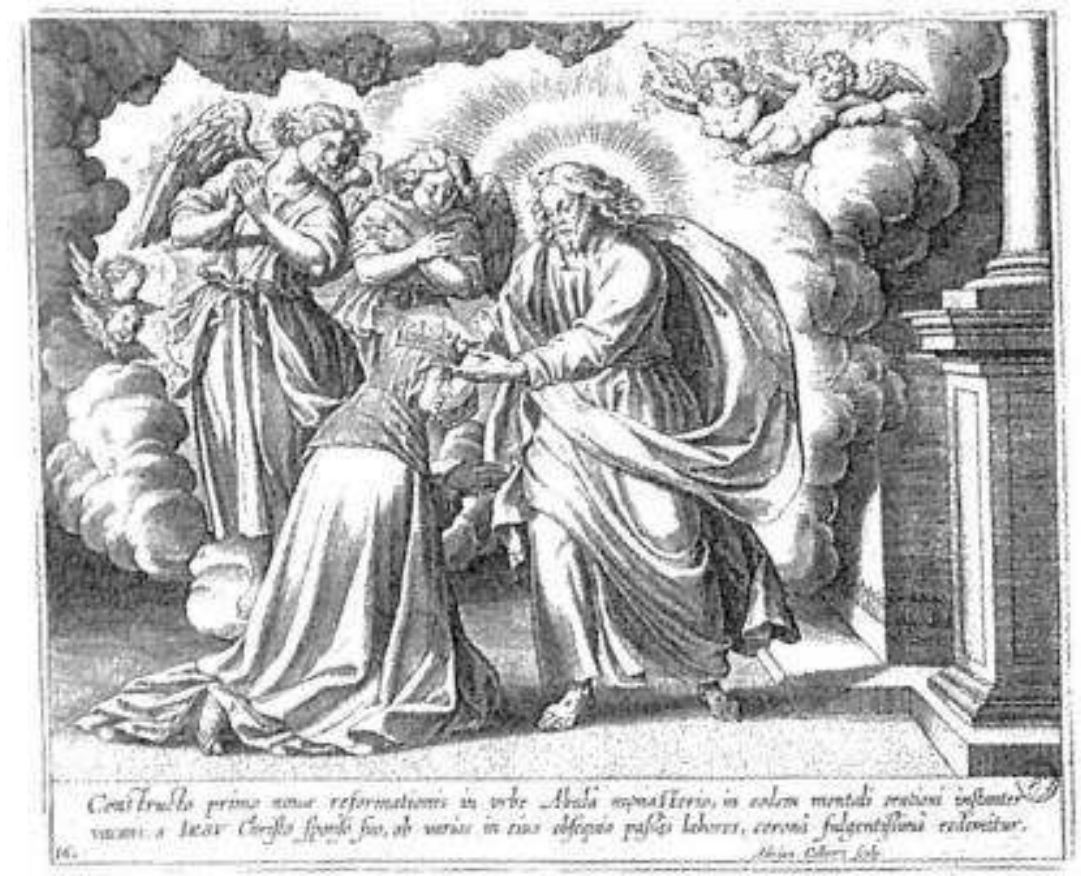

5. Santa Teresa coroada por Cristo

O Livro da Vida, primeira e mais extensa obra da autora, foi redigido pela primeira vez em 1562, por ordem do seu confessor, o padre Domingo Báñez, e dividido em capítulos em 1565, por imposição do padre Garcia de Toledo. Além de um relato autobiográfico da infância e juventude, Teresa de Jesus narra ainda nessa obra as suas experiências místicas e relata a história da fundação do convento de São José de Ávila. ${ }^{12}$

A redacção do Livro das Fundações, composto por ordem do padre Jerónimo Ripalda iniciou-se em 1573, em Salamanca, e foi completada em Burgos passados dez anos. Escrito durante a caminhada da Santa, à medida que se foi expandindo a Reforma e foram surgindo novos conventos, ele relata a história e a origem das diversas Fundações. O texto repete os temas habituais, de espiritualidade e conselhos para a direcção das religiosas.

Será então, sobretudo baseadas nestas fontes, mas também no contacto pessoal de que haviam desfrutado, que Ana de Jesus e Ana de São Bartolomeu procederam à selecção dos assuntos. Evidenciando claramente a intenção de exaltar e enaltecer as virtudes e graças de que havia gozado a sua Mestra, os episódios seleccionados destacam em particular aspectos místicos e ascéticos da existência de Santa Teresa. Prevalecem em especial as 
suas célebres visões, êxtases e contemplações, em detrimento de outros passos da sua vida, como é o caso da juventude e das Fundações.

Com um total de vinte e cinco gravuras, o álbum em análise é composto por portada, seguida de vinte e quatro estampas seriadas e legendadas em latim. A sequência inicia-se no número dois e termina no número vinte e cinco, apresentando as seguintes representações: ${ }^{13} 2$ - efígie de Santa Teresa; 3 - Santa Teresa e o irmão caminhando para a terra dos mouros; 4 - Ingresso de Santa Teresa no convento de Ávila; 5 - Santa Teresa enferma; 6 - Santa Teresa orando diante do Ecce Homo; 7 - Santa Teresa penitenciando-se das tentações do demónio; 8 - Transverberação de Santa Teresa; 9 - Santa Teresa com São Pedro e São Paulo; 10 - Filia tota mea es et ego totus tuus; 11 - Santa Teresa perante a Trindade; 12 - Santa Teresa superando as tentações do demónio; 13 - Esponsais místicos de Santa Teresa; 14 - Imposição do colar e do manto a Santa Teresa; 15 - Santa Teresa devolvendo a vida ao sobrinho; 16 - Santa Teresa coroada por Cristo; 17 - Levitação de Santa Teresa perante a Eucaristia; 18 - Santa Teresa com São João da Cruz e António de Jesus; 19 - Santa Teresa protectora dos carmelitas; 20 - Viagem de Santa Teresa a Sala manca; 21 - Tentações de um sacerdote; 22 - Santa Teresa com São João da Cruz; 23 - Santa Teresa escritora inspirada pelo Espírito Santo; 24 - Morte de Santa Teresa; e 25 - Santa Teresa benzendo os carmelitas.

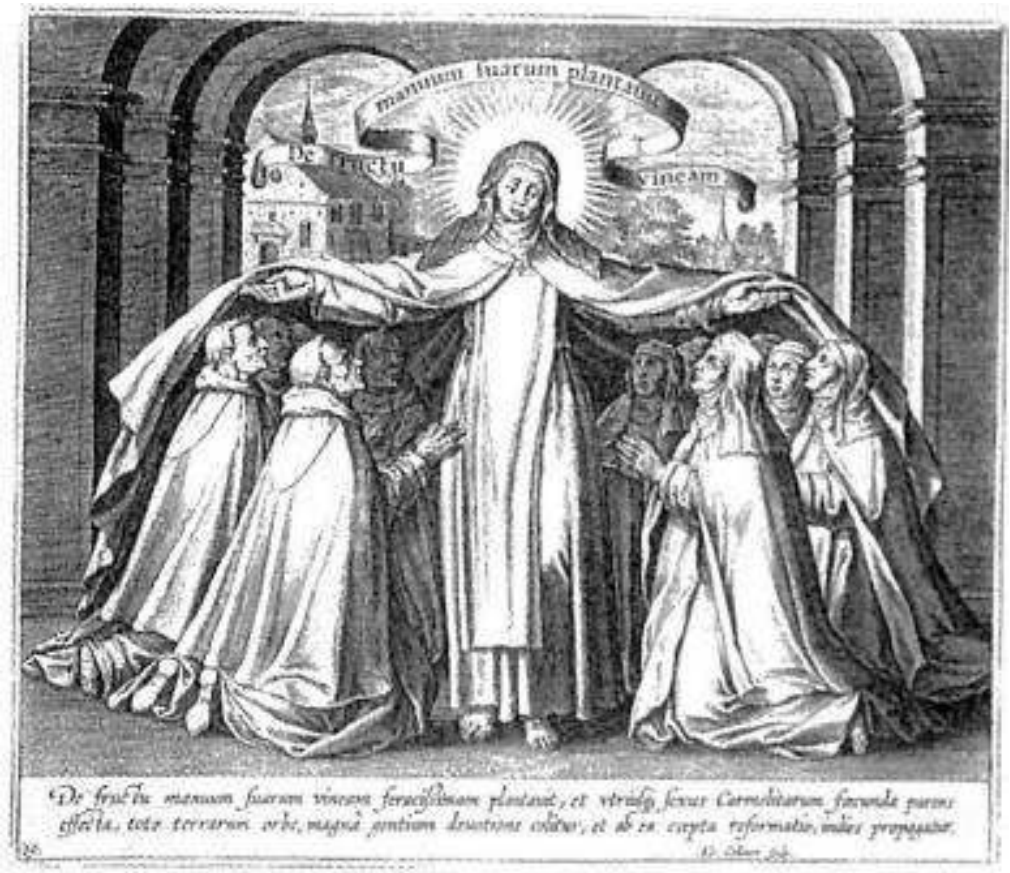

6. Santa Teresa protectora dos carmelitas

\section{A divulgação}

Época propícia para a disseminação das doutrinas teresianas, também a série de Amberes conheceu logo após a sua publicação uma enorme expansão, favorecida que foi pela atitude adoptada pela Igreja Católica após o Concílio de Trento. Pela importância que assumia a exaltação e o exemplo da vida dos santos, assiste-se então a uma popularização, sobretudo de índole didáctica e devocional, das suas representações. Neste contexto, gera-se um enorme consumo de imagens, galvanizado ainda pela possibilidade que a 
gravura oferecia de obter cópias em massa, que rápida e eficazmente podiam ser distribuídas nos principais circuitos comerciais do tempo.

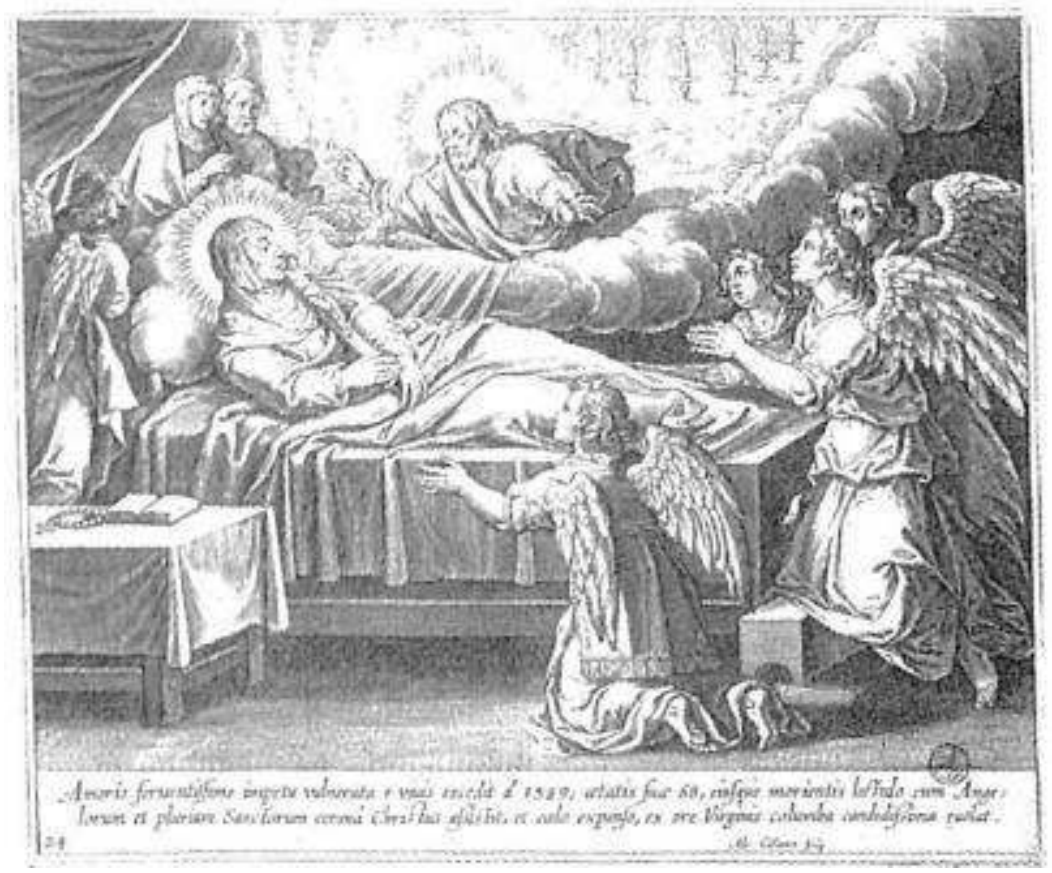

7. Morte de Santa Teresa

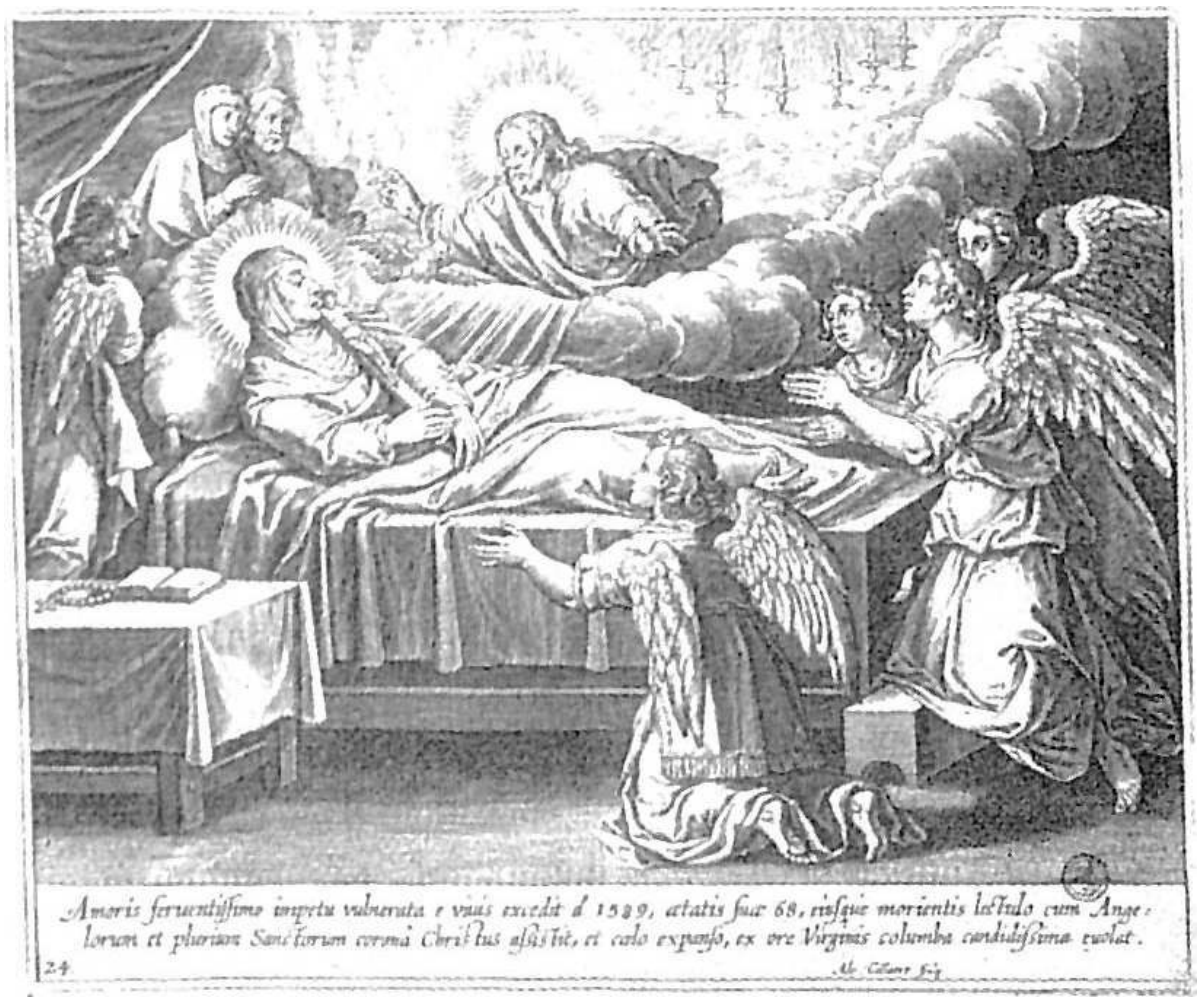

Incontroverso o facto de se ter constituído como um dos mais importantes veículos para a divulgação da vida dos santos, entre outras finalidades, a alusão aos episódios mais célebres da existência de Santa Teresa visava instruir os fiéis em diversos aspectos piedosos e devocionais. Sabe-se, por exemplo, que no convento carmelita de Medina del Campo, as vinte e quatro gravuras que constituem a série foram fixadas sobre tábuas, 
configurando uma narração sequencial com a qual as noviças do carmelo se instruíam acerca dos principais acontecimentos da vida da madre Fundadora. Além deste objectivo pedagógico, algumas séries serviam simplesmente para ornamentar as dependências conventuais.

Porém, o êxito de tais composições seria sobretudo visível quando estas se convertem num modelo corrente para inúmeras obras de arte, especialmente no domínio da pintura e da azulejaria. Com uma importância decisiva na fixação e desenvolvimento de parte da iconografia teresiana, as estampas de Amberes constituíram-se, desde logo, como um eficaz veículo para a rápida difusão da sua biografia.

Decorando o interior de inúmeros carmelos espalhados por todo o mundo, a verdade é que a série, completa ou incompleta, acabava também por essa via, por cumprir a sua função didáctica primordial. Com efeito, vários artistas se inspiraram na gravuras de Collaert e Galle, que foram, nalguns casos, rigorosamente copiadas. ${ }^{14}$

O enorme sucesso da edição de Antuérpia abre assim portas à publicação de diversas outras séries gravadas da vida de Santa Teresa, desde a cópia integral até às versões mais abreviadas. Apesar das semelhanças com as gravuras originais, o seu conhecimento assume especial importância, na medida em que foi por vezes nestas obras posteriores, e não nas primeiras, que se inspiraram diversos artistas plásticos ao longo dos tempos. Entre essas, foram especialmente divulgadas as seguintes:

- Giovanni Giacomo Rossi (1640-1690), Sanctissimae Matris Dei Monte Carmelo Beatae Teresiae humilis filiae ac devotae famulae effigies, 1622. Série publicada como original, composta de portada e vinte e quatro gravuras. Foi dedicada ao cardeal I Garsia Millino, vigário do Papa e protector do carmelo da antiga observância. Trata-se de uma cópia da série de Collaert e Galle, mas assinada por loannes Eillart Frisius, da qual existe em Portugal um exemplar na Biblioteca da Ajuda. ${ }^{15}$

- Isabella Duca, S. Teresa virgo fratrum Carmelitarum discalceatorum et monialium fundatrix relata intersanctos A. S. D. N. Gregório XV die 12 martii 1622 Romae, c. 1622. Versão simplificada da série de Antuérpia, trata-se de uma biografia de Santa Teresa, ilustrada com doze gravuras, claramente inspiradas no conjunto de Amberes, ainda que realizadas com diferentes critérios estilísticos e noutro formato. Sem data de edição, vieram à luz por ocasião da canonização de Santa Teresa (1622).

- Daniel a Virgine Maria, Konste der konsten ghebedt: oft maniere om wel te bidden besonderlijck ghetrocken uijt de schriften van de H. moeder Teresa de Iesu, Amberes, 1646. Incluindo doze gravuras biográficas anónimas, revela já uma influência mais exígua da série de Antuérpia. Para consumo devocional claro, em 1711, também em Amberes, sairá uma terceira edição desta obra. ${ }^{16}$

- Claudine Brunand, Vie de la Séraphique Mère Sainte Thérèse de Jésus, Fondatrice des Carmes Dechaussez et des Carmélites, en figures et en vers français et latins, Lyon, Antoine Jullieron imprimeur et Libraire du Roi, 1670. Com um conjunto de cinquenta e cinco gravuras, trata-se de uma obra dedicada à rainha Maria Teresa de Austria. ${ }^{17}$

- Arnold van Westerhout (1651-1725), Vita Effigiata Della Serafica Vergine S. Teresa di Gesú, Romae, Westerhout, 1716. Obra dedicada a Francesco Farnese (1679-1730/1), duque de Parma, apresenta um total de setenta estampas a buril $(176 \times 125 \mathrm{~mm})$, incluindo um retrato de Santa Teresa e sessenta e sete cenas numeradas da sua vida. Todas as representações apresentam inscrições em latim, e são assinadas pelo gravador Arnold van Westerhout. ${ }^{18}$

- Anastasio de la Cruz, Vita S. V. Et M. Theresiae a Iesu solis zodiaco parallela, Augsbourgo, 1750-60. Com treze gravuras da autoria de C. Klauber Cath. (1740-1760). 


\section{A sala de Santa Teresa}

É na denominada sala de Santa Teresa, que mais claramente se individualiza a iconografia teresiana no convento do Santíssimo Coração de Jesus. Local que funcionava em tempos de clausura como portaria, é aí que se encontra a representação de alguns dos principais passos da sua vida, visões e experiências místicas. De exíguas dimensões, trata-se de um espaço decorado por um silhar de azulejos, marcado por uma linguagem estilística tardia e assinalado por cercaduras policromas de feição Rocaille.

Obra integrada numa primeira campanha ornamental levada a cabo no edifício, que datámos entre 1780 e $1790,{ }^{19}$ as composições dos dez painéis figurativos foram concebidas a partir da cópia de dez das gravuras do álbum Vita S. Virginis Teresiae a Iesv. Com as características próprias da habitual ingenuidade, patente na pintura de azulejo, a série de Amberes teve no convento do Santíssimo Coração de Jesus uma das suas réplicas mais expressivas.

Como é sabido, também em Portugal a circulação de livros de gravuras com temas religiosos era frequente, bem como a sua utilização por artífices e pintores. Com uma função devocional e didáctica, as estampas com episódios da vida de Santa Teresa, deverão também ter chegado ao carmelo da Estrela. Normalmente cedidas pelo próprio encomendador, muitas dessas composições eram copiadas integral ou parcialmente, sobretudo por questões de correcção iconográfica, mas também para obedecer ao gosto do promotor da obra. Talvez por via do convento de Santa Teresa em Carnide, de onde provinham as madres fundadoras, ou simplesmente facultadas ao artífice para que pudesse realizar o seu trabalho, à escolha dos temas presidiram critérios definidos.

No programa iconográfico seleccionado para esta dependência do convento da Estrela, reconhece-se que ficaram de lado representações tão importantes quanto a Transverberação (grav. n. ${ }^{\circ}$ ), os Esponsais Místicos (grav. n. ${ }^{\circ} 13$ ), a Coroação (grav. n. ${ }^{\circ} 16$ ) ou a Morte (grav. n. ${ }^{\circ} 24$ ). Assuntos habitualmente representados noutros conventos da Ordem, e presença obrigatória nas principais narrativas gráficas teresianas, esta ausência pode ser explicada pelo facto dos mesmos episódios se encontrarem ilustrados noutras zonas do cenóbio. Por outro lado, dadas as exíguas dimensões da portaria, a eleição de alguns dos temas pode também ter sido norteada pelo objectivo de adequar mais eficazmente os painéis ao espaço. Ocasionando a representação de episódios pouco habituais, entre a rica e vasta iconografia de Santa Teresa, reconhece-se ainda que os assuntos foram agrupados de acordo com a sequência cronológica dos acontecimentos, aspecto que de resto se verifica naturalmente nas gravuras de Antuérpia.

Quanto à adaptação das fontes ao azulejo, reconhece-se que os artistas alteraram as estampas em função do espaço disponível, aumentando ou diminuindo os painéis de acordo com a morfologia e dimensão da superfície a revestir. Procedimento habitual em azulejaria, na portaria da Estrela, o silhar desenvolve-se em torno da sala, iniciando-se a leitura narrativa a partir da porta de acesso. Mantendo sempre intactas as cenas principais, aquilo que por norma se modificou foram os enquadramentos. Deste modo, foram abreviados os painéis correspondentes às gravuras $n .^{\circ} 7,14$ e 15, e ampliado o que reproduz a gravura n. $^{\circ} 6$, pelo acréscimo de elementos arquitectónicos, inexistentes na estampa e derivados, muito provavelmente, da imaginação do executante. 
Se, em verdade, o artista opera algumas transformações, o facto é que tal sucede quase sempre para efeitos de adequação da estampa à superfície a decorar. Com composições que raramente derivam da sua própria interpretação pessoal, mais seguramente, as variações se explicam pela existência de fontes diversas, nomeadamente em termos estilísticos, compositivos e de tratamento temático.

No caso do conjunto dos Cardaes, José Meco reconhece a liberdade apócrifa do pintor, pela inclusão de personagens sem relação com os episódios narrados, assim como pelo facto da concepção geral e organização plástica de cada cena ter ficado ao critério do artista. ${ }^{20} \mathrm{~A}$ conjugação de temas alheios à iconografia geral do espaço, sintomática de uma intervenção bastante mais activa, reflecte também o recurso a fontes diversas.

Apesar de se encontrar na Estrela uma parte bastante significativa da iconografia de Santa Teresa, nomeadamente cenas da vida e visões da mística de Ávila, não devemos deixar de assinalar ainda o importante conjunto de três painéis de azulejos da antiga casa do capítulo do convento de Santa Marta em Lisboa, de religiosas clarissas, que se baseia também directamente no álbum de Amberes. ${ }^{21}$

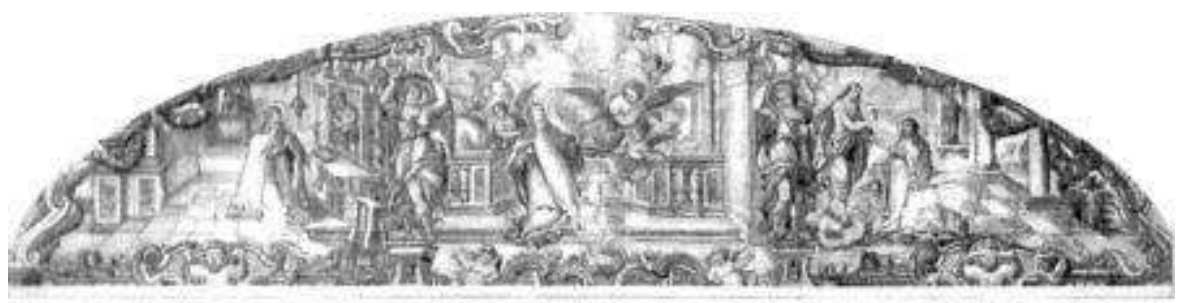

8. Azulejos da antiga casa do capítulo, Convento de Santa Marta, Lisboa

Com efeito, a iconografia de Teresa de Jesus, sobretudo representada nos diversos conventos das carmelitas, estendeu-se igualmente a outros locais, onde se podem também encontrar cenas narrativas da sua vida. A hegemonia da Santa de Ávila em domínios diversos, explica a presença da sua iconografia em conventos de outras ordens religiosas.

A sua qualidade de Reformadora, determinante como é sabido para o aspecto eremítico da Ordem Carmelita Descalça, serviu também de pretexto para diversas representações suas em cenóbios dessa natureza, de que é exemplo o convento alentejano de São Paulo da Serra de Ossa. ${ }^{22}$

Também pelo facto de ter sido madre superiora de uma comunidade feminina, contribuiu para que tivesse sido tema de eleição na decoração de diversas outras casas religiosas, figurando nesses casos, com as insígnias próprias do cargo, um anel e uma cruz peitoral. Enquanto escritora, foi representada com vários instrumentos de escrita, nomeadamente o tinteiro, o livro, a pena e a ampulheta, assim como a pomba do Espírito Santo, símbolo da inspiração e sublimidade dos seus escritos.

Mas foram as suas experiências místicas, sobretudo as visões e os êxtases, que mais inspiraram os artistas e que maior número de temas ocasionaram, distinguindo-se como principais atributos um anjo serafim com uma flecha flamejante, um coração em chamas ou radiante, trespassado ou não, um manto protector e um colar.

Porém, será nos conventos de carmelitas descalças que se encontra a mais vasta e rica iconografia de Teresa de Jesus, de que são exemplos célebres: o conjunto de pinturas do extinto cenóbio de Cascais, realizado por Josefa de óbidos em $1672 ;{ }^{23}$ os revestimentos azulejares do convento dos Cardaes $^{24}$ e de Carnide, ambos em Lisboa; assim como os painéis da capela de Santa Teresa, em Caldas de Monchique. 
No tocante ainda à série de Amberes, José Meco aponta afinidades estilísticas entre os painéis do coro-alto da já referida igreja dos Cardaes e os três painéis do convento de Santa Marta, assinalando a influência da série de 1613. Considerando terem sido usadas parcialmente, indica ainda como fonte as gravuras realizadas em 1716 por Arnold van Westerhout e a conhecida estampa de Wierix para o painel da Transverberação. ${ }^{25}$

Apesar de terem, sem qualquer dúvida, desempenhado um papel determinante na iconografia de Santa Teresa de Ávila, as gravuras de Collaert e Galle impulsionaram, como vimos, a produção de outros conjuntos de estampas, que oscilaram entre as doze e as setenta gravuras no total.

As subtilezas que as distinguem, por vezes através da simplificação das composições, da supressão de alguns elementos ou por divergências ao nível dos cenários, determinam todavia inspirações diversas. Exigindo por isso um cotejo mais rigoroso, entre as obras de arte e as suas hipotéticas fontes, é precipitado, por vezes até desacertado, o uso sistemático da série de Amberes para base de inúmeras obras alusivas a Santa Teresa. Normalmente apontadas como a principal fonte de inspiração das representações relativas à sua vida, por serem, com efeito, a sua mais divulgada e célebre biografia gravada, essa insistência conduz por vezes à errada comparação de modelos que, em verdade, não se relacionam com as obras em análise.

- Santa Teresa e o irmão caminham para a terra dos mouros

Gravura n. ${ }^{\circ}$, Silhar de 5 x 15 azulejos (excluindo cercadura)
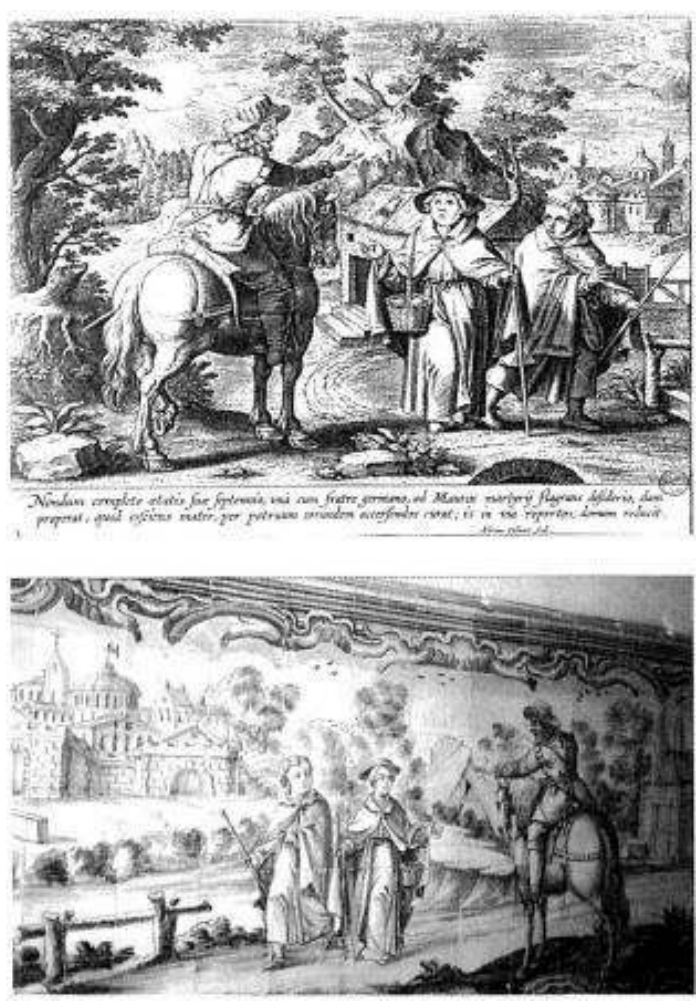

9. Santa Teresa e o irmão caminham para a terra dos mouros

Ainda sem ter completado sete anos de idade, Teresa foge com o seu irmão Rodrigo para a terra dos Mouros. A cena representada ilustra o momento em que o pai os descobre duran te essa caminhada, fazendo-os voltar para casa. Episódio relacionado com a sua infância, é curioso notar que no coro-alto do convento dos Cardaes os dois irmãos sejam 
representados, não como crianças mas como adolescentes. O episódio é descrito por Teresa de Jesus no Livro da Vida:

"Meus irmãos em coisa alguma me desajudavam a servir a Deus. Tinha um, quase da minha idade, que era aquele a quem eu mais queria embora a todos tivesse grande amor e eles a mim. (...) Combinámos ir a terra de mouros, esmolando por amor de Deus, para que lá nos decapitassem; e parece-me que nos dava o Senhor ânimo em tão tenra idade, se víssemos algum meio; mas o termos pais parecia-nos o maior embaraço." 26

- Ingresso de Santa Teresa no mosteiro de Ávila

Gravura $n .^{\circ} 4$, Silhar de $5^{\times} 12$ azulejos (excluindo cercadura)
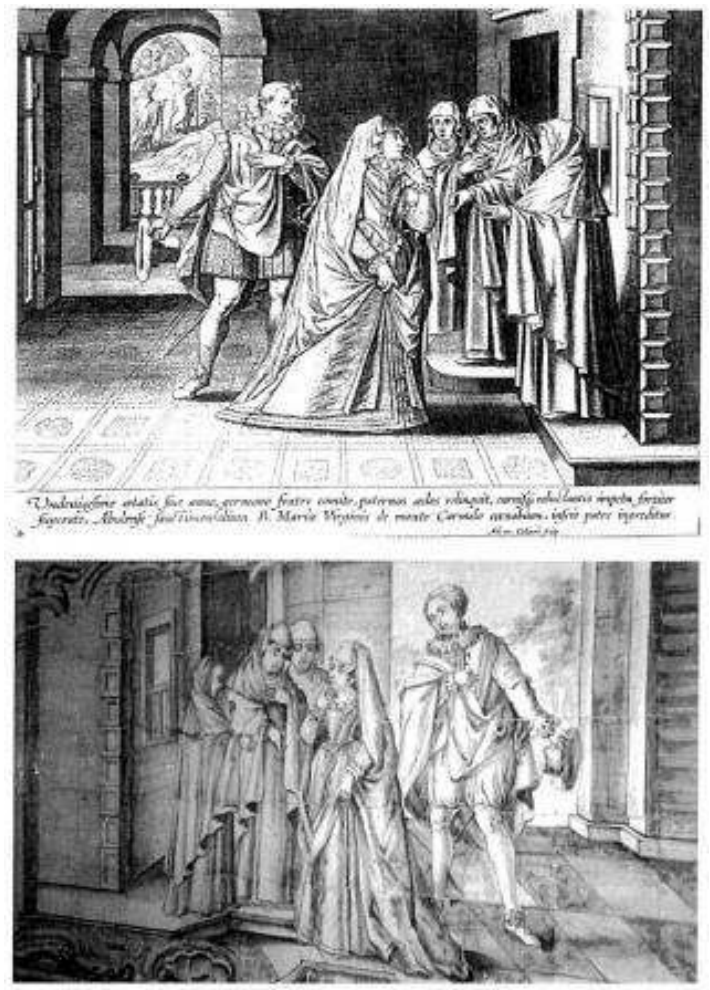

10. Ingresso de Santa Teresa no mosteiro de Ávila

Ilustra a passagem de Teresa de Jesus para a vida cenobítica. Com dezanove anos, na companhia do irmão António e sem que seu pai soubesse, ingressa no mosteiro carmelita de Ávila. Momento autobiográfico da Santa, o episódio foi uma vez mais narrado pela autora, que recorda:

"Nestes dias em que andava com estas determinações havia persuadido a um irmão meu a que se fizesse frade, falando-lhe da vaidade do mundo. E combinámos entre nós, ir um dia, muito de manhã, ao mosteiro onde estava aquela minha amiga a quem eu tinha muita afeição. Nesta minha última determinação já eu estava de modo que iria para qualquer convento onde pensasse servir mais a Deus ou que meu pai quisesse. (...) Recordo-me (...) que quando saí de casa de meu pai foi tal a aflição que não creio será maior quando eu morrer. (...) se o Senhor não me ajudara, não teriam bastado as minhas considerações para ir por diante. Aqui deu-me o Senhor ânimo contra mim, de maneira que o pus por obra. Em tomando o Hábito, logo o Senhor me deu a entender como favorece aos que se esforçam para $\mathrm{O}$ servir." ${ }^{27}$

\section{- Santa Teresa orando diante do Ecce Homo}

Gravura n. ${ }^{\circ}$, Silhar de 5 x 12 azulejos (excluindo cercadura) 

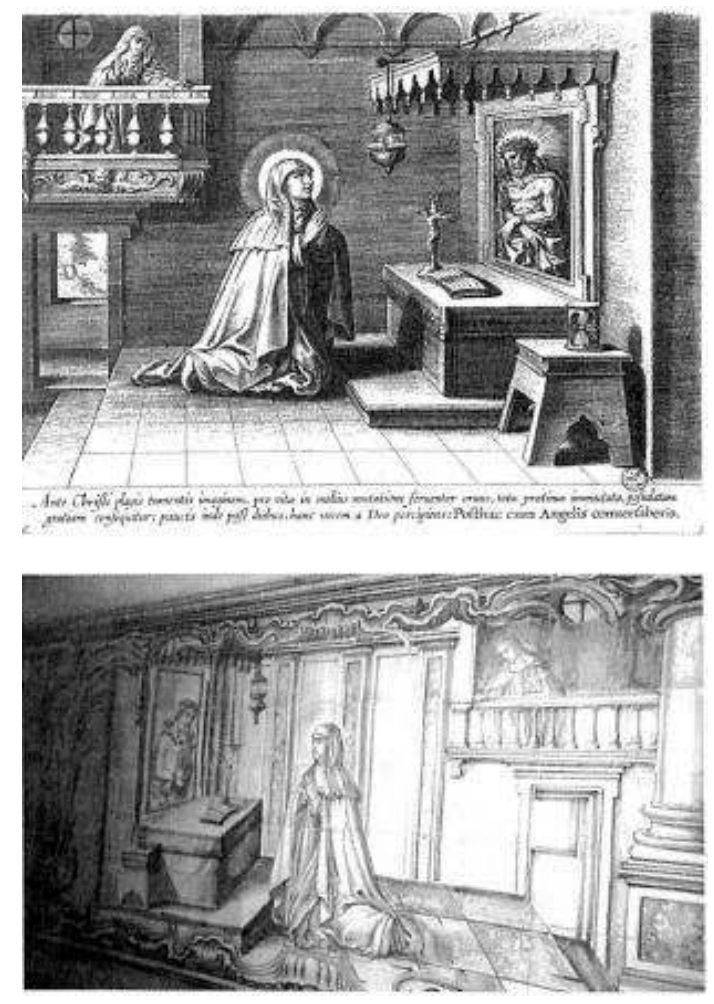

11. Santa Teresa orando diante do Ecce Homo

Representa uma das experiências místicas de Santa Teresa que, rezando diante da imagem de Cristo com as chagas intumescidas, consegue a graça pedida e, poucos dias depois, ouve a voz de Deus que lhe diz: daqui em diante viverás com os anjos:

"Aconteceu-me que, entrando eu um dia no oratório, vi uma imagem, que para ali trouxeram a guardar (...). Era a de Cristo muito chagado e tão devota que, ao pôr nela os olhos toda eu me perturbei por 0 ver assim (...). Foi tanto o que senti por tão mal Lhe ter agradecido aquelas chagas, que o coração, me parece, se me partia e arrojei-me junto d'Ele com grandíssimo derramamento de lágrimas, suplicando-Lhe me fortalecesse de uma vez para sempre para não 0 ofender." ${ }^{28}$

- Santa Teresa penitencia-se das tentações do demónio

Gravura n. $^{\circ}$, Silhar de 5 x 5 azulejos (excluindo cercadura) 

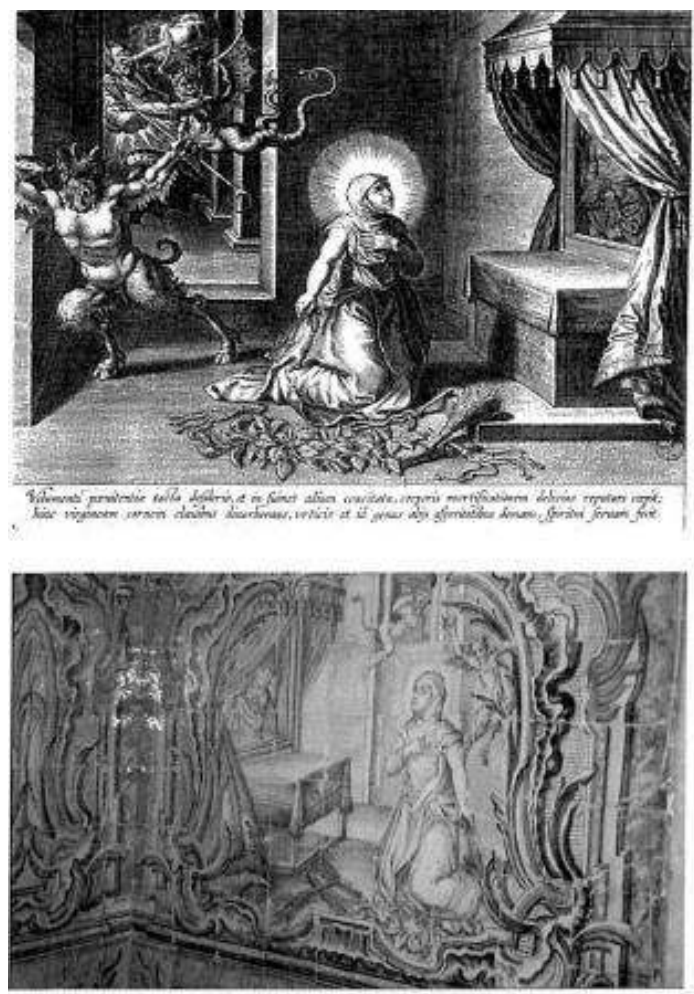

12. Santa Teresa penitencia-se das tentações do demónio

Episódio autobiográfico relatado por Santa Teresa enquanto freira, representa o momento em que esta se penitencia violentamente com chaves, urtigas e outros cilícios:

"Parece-me bem falar de algumas tentações que tenho visto haver de principio algumas tenho-as eu tido (...) Pensar que nos podemos esforçar com o favor de Deus a ter um grande desprezo do mundo, a não estimar honras, nem estar atido à fazenda. Temos uns corações tão apertados, que parece nos há-de faltar a terra em querendo-nos descuidar um pouco do corpo para darmos ao espírito. (...) A mim, isto me pesa; termos tão pouca confiança em Deus e tanto amor próprio, que nos inquiete este cuidado. (...) Parece-me agora a mim, esta maneira de caminhar um querer conciliar corpo e alma para não perder cá na terra o descanso e gozar lá no Céu de Deus." 29

\section{- Santa Teresa com São Pedro e São Paulo}

Gravura n. ${ }^{\circ}$, Silhar de 5 x 8 azulejos (excluindo cercadura) 

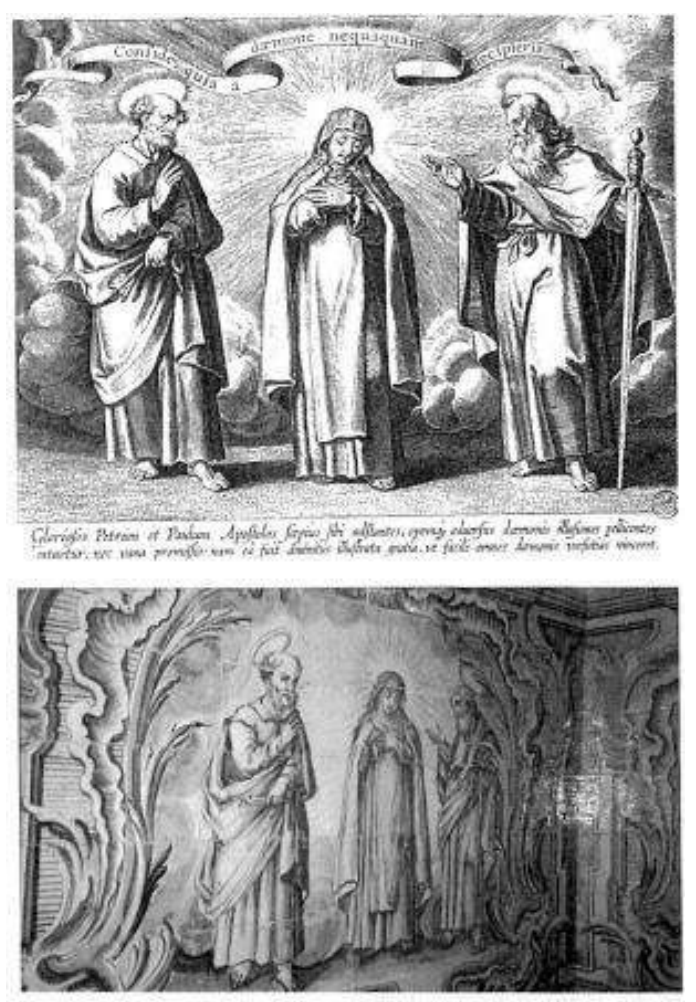

13. Santa Teresa com São Pedro e São Paulo

Trata-se de uma representação que ilustra a visão de São Pedro e São Paulo, que prometem a Santa Teresa auxílio contra as ilusões tentadoras do demónio. No corpo da gravura lê-se confia porque de modo nenhum serás enganada pelo demónio. Porque as suas visões eram excessivas, um dos seus confessores fala-lhe sobre a influência do demónio.

"Suplicava muito ao Senhor que me livrasse de ser enganada (...) e pedia a S. Pedro e a S. Paulo porque o Senhor me disse (...) que eles me guardariam para que não fosse enganada. $\mathrm{E}$ assim os via muitas vezes ao meu lado esquerdo muito claramente, embora não por visão imaginária. Eram estes gloriosos santos muito meus senhores." 30

\section{- Santa Teresa supera as tentações do demónio}

Gravura n. ${ }^{\circ} 12$, Silhar de 5 x 8 azulejos (excluindo cercadura) 

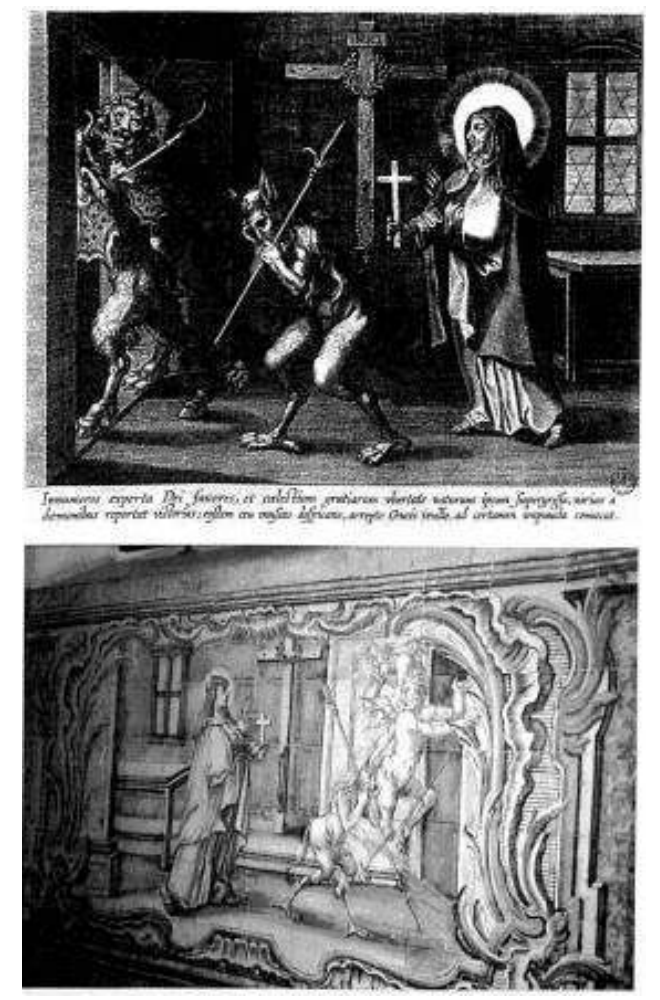

14. Santa Teresa supera as tentações do demónio

Representa outra das suas visões na qual, contemplada pelas inúmeras graças de Deus, ultrapassou a própria natureza com a abundância dos favores divinos. Impávida, e empunhando um crucifixo, alcançou várias vitórias sobre os demónios. Relatanto este episódio, Santa Teresa escreve:

“(...) vi ao pé de mim um negrito muito abominável, raivando como desesperado porque perdia onde pretendia ganhar. Eu, quando o vi, ri-me e não tive medo. (...) De muitas outras vezes tenho experiência que não há coisa de que eles fujam mais e para não voltar. Da cruz também fogem, mas voltam." ${ }^{31}$

- Imposição do colar e do manto a Santa Teresa

Gravura.$^{\circ} 14$, Silhar de 5 x 5 azulejos (excluindo cercadura) 


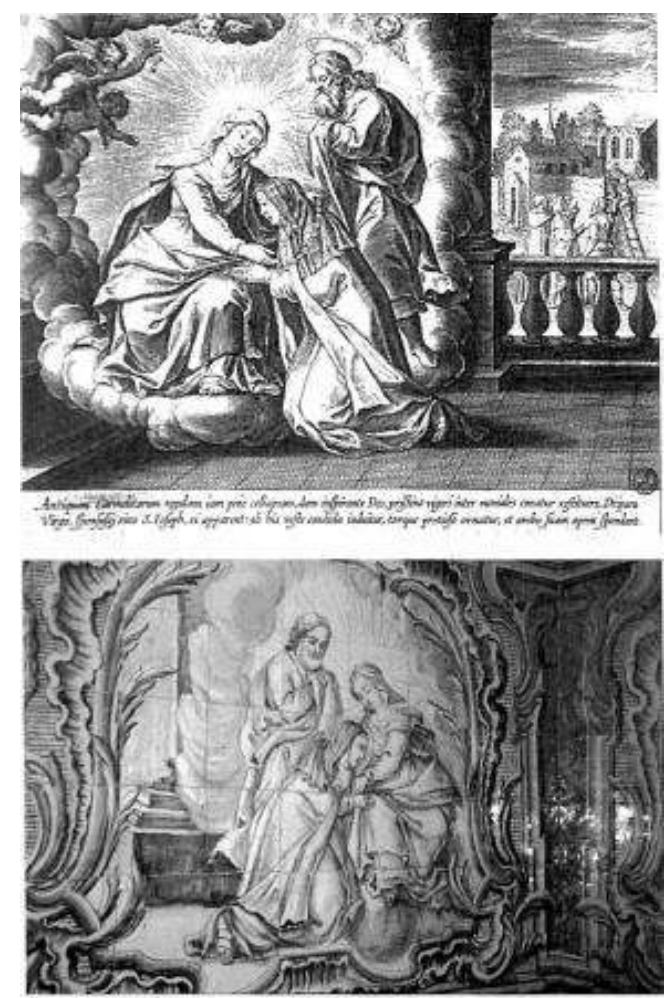

15. Imposição do colar e do manto a Santa Teresa

De acordo com a descrição de Teresa de Jesus, esta visão teve lugar em 1561, no dia de N. S. da Assunção, na igreja de São Tomás de Avila. Esforçando-se por restabelecer no primitivo vigor a antiga regra das Carmelitas, esta representação assinala o momento em que São José a cobre com um manto branco, a Virgem lhe entrega um colar de ouro, e ambos lhe prometem assistência. Trata-se de uma das suas visões mais célebres, fundamental para a Ordem Carmelita Descalça, pois afiança em Teresa de Jesus o empenho de reformar a Ordem. Encontrando-se então na igreja do convento dominicano referido:

"Parecia-me, estando assim, que me via vestir de uma veste de muita brancura e claridade. A princípio não via quem ma vestia; depois vi a Nossa Senhora a meu lado direito e a meu Pai S. José à esquerda, que me vestiam aquela roupa. Deu-se-me a entender que já estava limpa de meus pecados. Acabada de vestir (...) logo me pareceu Nossa Senhora pegar-me nas mãos. Disse-me que Lhe dava muito gosto sendo devota do glorioso S. José; que tivesse por certo o que eu pretendia do mosteiro se havia de fazer e nele se serviria muito o Senhor e a eles ambos; que não temesse que nisto houvesse jamais quebra, embora a obediência que dava não fosse a meu gosto. Eles nos guardariam e já Seu Filho nos tinha prometido andar connosco. Para sinal de que isto se cumpriria dava-se aquela jóia. Pareceu-me então que me tinha deitado ao pescoço um colar de ouro muito formoso e preso a ele uma cruz de muito valor. (...)"32

- Santa Teresa devolve a vida ao sobrinho

Gravura n. ${ }^{\circ} 15$, Silhar de 5 x 6 azulejos (excluindo cercadura) 


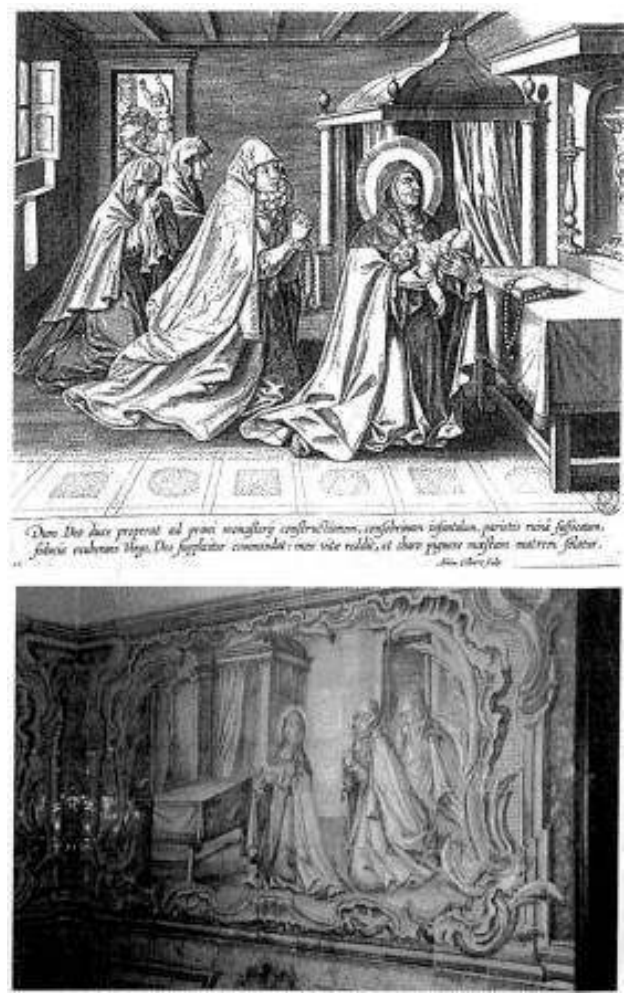

16. Santa Teresa devolve a vida ao sobrinho

Representa um outro momento da vida da Santa, que teve lugar logo no início das suas Fundações. Apressando-se na construção do primeiro mosteiro da Reforma (São José), a queda de uma parede provocaria a asfixia do seu pequeno sobrinho Gonzalo Ovalle, filho de sua irmã Juana de Ahumada. Voltando imediatamente à vida, reconforta a triste mãe que assiste. As representações deste tema seguem com fidelidade as suas narrações, ao relatar a fundação do mosteiro de São José:

"Outra vez estava uma pessoa muito mal de uma enfermidade muito penosa (...). Era coisa incomportável o que padecia havia já dois meses. Estava num tormento que se despedaçava. Foi vê-la o meu confessor (...) e causou-lhe grande lástima e disse-me que de todo o modo a fosse ver, pois era pessoa a quem o podia fazer, por ser meu parente. Fui e comovi-me a ponto de ter tanta compaixão dele, que comecei a pedir importunamente a sua saúde ao Senhor. Nisto vi claramente, sem me ficar qualquer dúvida, a mercê que me fez; porque logo no outro dia estava de todo bom daquela dor." ${ }^{33}$

\section{- Santa Teresa com São João da Cruz e António de Jesus}

Gravura n. ${ }^{\circ} 18$, Silhar de 5 x 8 azulejos (excluindo cercadura) 

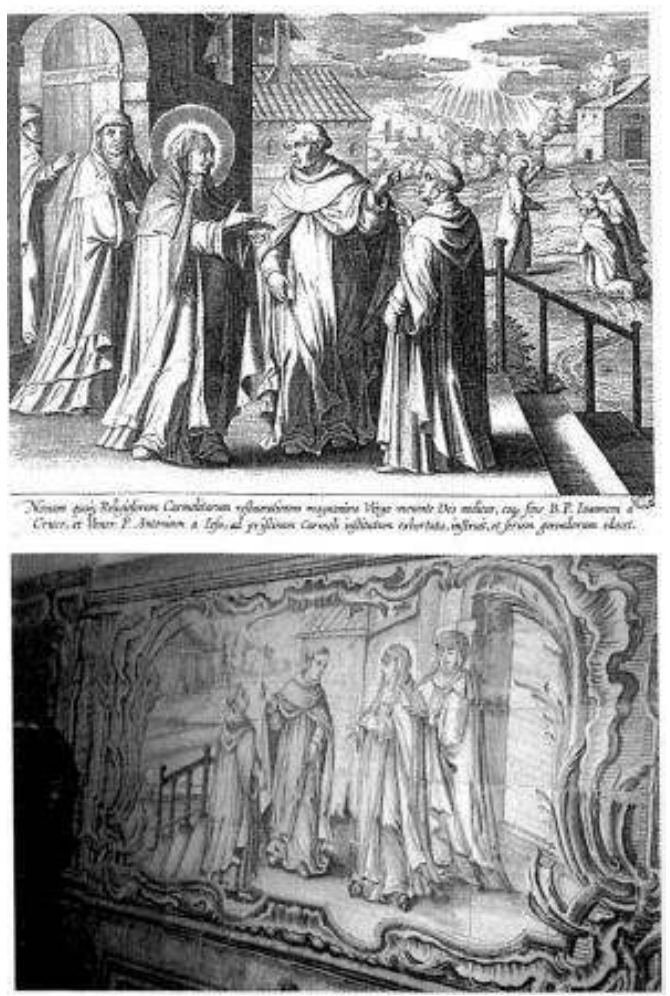

17. Santa Teresa com São João da Cruz e António de Jesus

Trata-se de um episódio associado já ao período da Reforma, ocorrido antes da fundação do convento de Nossa Senhora do Carmo de Valladolid, em 1568. Encorajada pelo primitivo projecto do Carmelo, esta representação ilustra o momento em que Santa Teresa fala com São João da Cruz e o Padre António de Jesus, incumbindo-os de urna série de tarefas. De acordo com o seu relato:

"Ainda antes de ir para a fundação de Valhadolid, tinha combinado (...) com o Padre Frei António de Jesus (...) e com Frei João da Cruz, que seriam eles os primeiros a entrar, no caso de se fazer mosteiro de Descalços da Regra Primitiva; (...) encarreguei o Padre Frei António de angariar qualquer coisa para a casa e parti com Frei João da Cruz para a dita fundação de Valhadolid. Estivemos alguns dias sem clausura para que os operários fizessem o que era exigido para o recolhimento da casa. Assim, havia ocasião de informar Frei João da Cruz acerca de toda a nossa maneira de proceder, para que levasse bem entendidas todas as coisas (...)." ${ }^{134}$

- Santa Teresa escritora inspirada pelo Espírito Santo

Gravura n. ${ }^{\circ} 23$, Silhar de 5 x 8 azulejos (excluindo cercadura) 

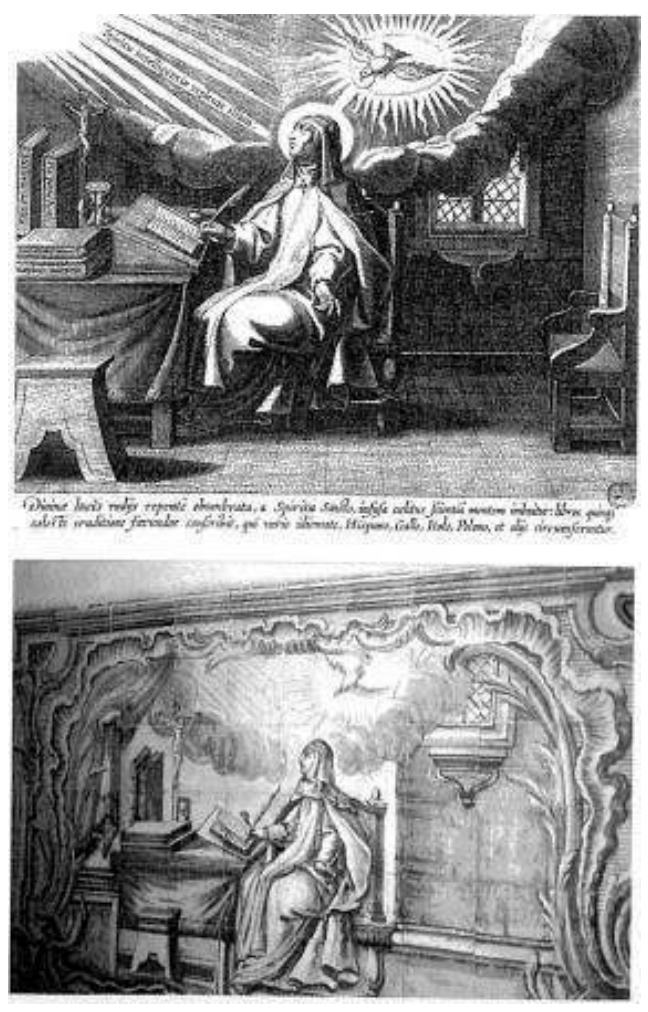

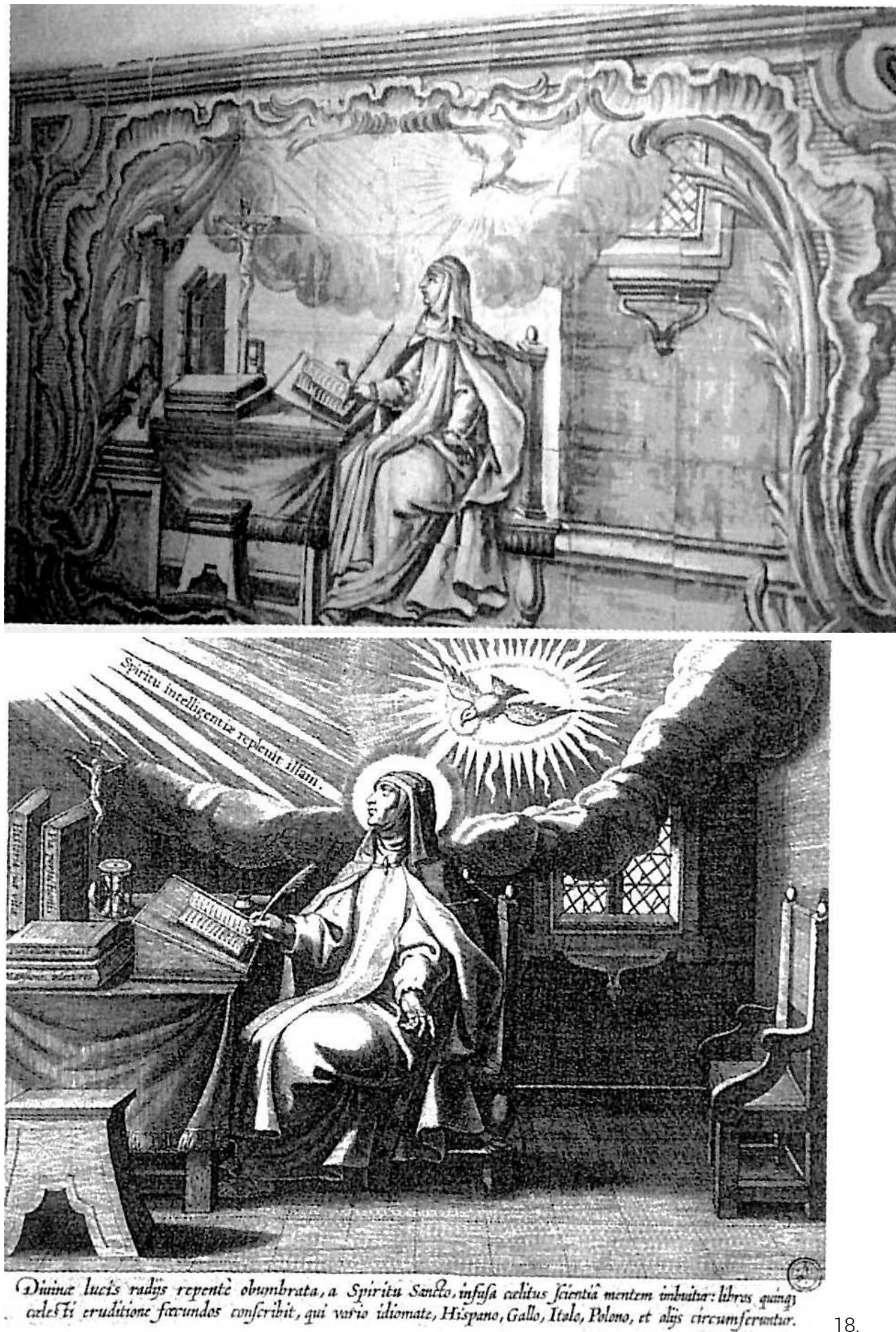

Santa Teresa escritora inspirada pelo Espírito Santo

A representação mais frequente de Teresa de Jesus é a que faz referência à sua condição de escritora. Na cena em questão, que não alude a nenhuma passagem concreta da sua vida, a presença da pomba do Espírito Santo figura como a fonte de inspiração da mística escritora, como a luz divina que a envolvia quando escrevia as suas obras. O Espírito Santo, atributo frequente na iconografia cristã, caracteriza os doutores da igreja. No caso de Santa Teresa é também uma alusão directa às suas diferentes visões, invocada diversas vezes nos seus próprios escritos: 
"Estando nesta consideração, deu-me um ímpeto grande sem entender o motivo; (...) Era ímpeto tão excessivo, que eu não o podia reprimir, (...) Nem entendia o que tinha a alma nem o que queria, que tão alterada estava. (...) Estando nisto, vejo sobre minha cabeça uma pomba, bem diferente das de cá, porque não tinha penas, senão que as asas eram de umas conchinhas que despediam de si grande resplendor (...). Certo é, Senhor meu e glória minha, que estou em dizer que, nestas grandes aflições que sente a minha alma, eu tenho de certo modo feito alguma coisa em Vosso serviço. Ai que já não sei o que digo, pois quase já não sou eu a falar ao escrever isto!" 35

\section{BIBLIOGRAFIA}

BRUNAND, Claudine, Vie de la Séraphique Mère Sainte Thérèse de Jésus, Fondatrice des Carmes Dechaussez et des Carmélites, Lyon, Antoine Jullieron imprimeur et Libraire du Roi, 1670. BRUNAND, Claudine, La Vie de la séraphique Mère sainte Thérèse de Jésus, Fondatrice des Carmes Deschaussés, en figures et en vers français et latins, $2^{\mathrm{a}}$ ed., Grenoble, L. Gilibert, 1678.

COLLAERT, Adriaen, GALLE, Cornelis, Vita B. Virginis Teresiae, Antuérpia, Apud Adrianum Collardum et Cornelium Galleum, 1613.

COLLAERT, Adriaen, GALLE, Cornelis, Vita S. Virginis Teresiae a Iesu Ordinis Carmelitarum Excalceatorum piae restauratricis, Antuérpia, Apud Ioannem Galleum, 1630.

JESUS, Santa Teresa de, "Fundações", Obras Completas, $3^{a}$ ed., Oeiras, Edições Carmelo, 1994, pp. 969-1231 (1 $1^{\mathrm{a}}$ ed. 1962).

JESUS, Santa Teresa de, "Livro da Vida", Obras Completas, $3^{a}$ ed., Oeiras, Edições Carmelo, 1994, pp. 3-390 (1ª ed. 1962).

VIRGINE MARIA, Daniel a, Konste der konsten ghebedt: oft maniere om wel te bidden besonderlijck ghetrocken uijt de schrifien van de H. moeder Teresa de Iesu, $2^{\mathrm{a}}$ ed., Ambers, Michiel Cnobbaert, 1669 (1를 ed. 1646).

ALONSO FERNÁNDEZ, María del Puerto, "Ana de Jesús, profeta de ayer y hoy", Revista de Espiritualidad, vol. 63, Madrid, Padres Carmelitas Descalços, 2004, pp. 251-299.

ARRUDA, Luísa, COELHO, Teresa Campos, "Os anjos porta-círios e Santa Teresa de Jesus", Convento de S. Paulo da Serra de Ossa, Lisboa, Edições Inapa, 2004, pp. 65-71.

AUCLAIR, Marcelle, Sainte Thérese D’Avila, s.l., Éditions du Seuil, 1950.

CARVALHO, Cristina Silva, Os azulejos de Santa Teresa de Ávila na Basílica da Estrela: projecto museológico (Trabalho curricular do curso de pós-graduação em Museologia e Património apresentado à Universidade Lusíada de Lisboa), Lisboa, 1995 (texto policopiado).

DÍAZ, José Hernández, "Memoración en un Centenario Teresiano", Boletín de Bellas Artes, n. ${ }^{\circ}$ IV, Sevilla, Academia de Bellas Artes de Santa Isabel de Hungria, 1976, pp. 25-37.

ESTEVEZ, Angel Bernal, Santa Teresa en la Historia y en el Arte, Ávila, s. ed., 1981. 
GARCÍA, M. Herrero, "El grabado al servicio de la mística", Revista de Ideas Estéticas, n. ${ }^{\circ} 11$, vol. III, Madrid, Conselho Superior de Investigações Científicas-Instituto Diego Velazquez, 1945, pp. 341-349.

HINAJEROS, Dolores Garcia, "Las Ideas Arquitectonicas de Santa Teresa de Jesus", I Congreso Internacional del Monacato Femenino en España, Portugal y America - 1492-1992, vol. I, Leon, Universidade de Leon, 1993, pp. 249-257.

JESUS, Juan Bosco de, "Las vidas gráficas de Santa Teresa en el grabado Barroco", Catálogo de la exposición Castillo Interior: Teresa de Jesus y el siglo XVI, Ávila, s. ed., 1995, pp. 367-373.

LEÓN, Fernando Ponce de, "Os painéis de azulejo sobre Santa Teresa de Jesus, no convento de Santa Marta de Lisboa", Museu, IV série, n. ํ 1, 1993, pp. 161-181.

MECO, José, "A Divina Cintilação: talha, azulejos, mármores, chinoiseries", Convento dos Cardaes: Veios da Memória, Lisboa, Quetzal Editores, 2003, pp. 109-188.

RUEDA, L. Gutiérrez, "Ensayo de iconografia teresiana", Revista de Espiritualidad, vol. 23, Madrid, Padres Carmelitas Descalços, 1964, pp. 1-168.

SAGGI, Ludovico, Santos del Carmelo, Madrid, Editorial de Espiritualidad, 1982.

SALDANHA, Sandra Costa, A Basílica da Estrela: Real Fábrica do Santíssimo Coração de Jesus, Lisboa, Livros Horizonte, 2006 (no prelo).

SANLLORENTE, Gloria, Carpeta gráfica teresiana, Burgos, Monte Carmelo 1981.

SANZ, Carlos, (Publ. por), Estampas de la vida de la Santa Madre Teresa de Jesús, Madrid, s. ed., 1962 (fac-símile da $1^{\text {a }}$ ed. Amberes, 1613).

SEBASTIÁN, Santiago, Contrarreforma y Barroco: Lecturas iconográficas e iconológicas, $3^{a}$ ed., Madrid, Alianza Editorial, 1989 (1 ed. 1981).

SEBASTIÁN, Santiago, "Iconografia de la vida mística teresiana: homenaje en el cuarto centenario", Boletín del Museo e Instituto Camón Aznar, T. X, Zaragoza, Museo e Instituto Camón Aznar, 1982, pp. 15-37.

SOBRAL, Luís de Moura, "Josefa d'óbidos e as Gravuras: problemas de estilo e de iconografia", Josefa de Óbidos e o tempo Barroco. Lisboa, T.L.P., 1991, pp. 51-69.

TALEGÓN, José Navarro, Iconografia de Santa Teresa en la Provincia de Zamora: exposición, Zamora, Caja de Ahorros Provincial, 1982.

URREA, Jesús, (Coord. de), Homenaje a Santa Teresa en el IV Centenario de su Muerte, Valladolid, Caja de Abonos Popular, 1982.

YUSTE, Belén, RIVAS-CABALLERO, Sonnia L., "Ana de San Bartolomé y la expansión del Carmelo Descalzo", Revista de Espiritualidad, vol. 63, Madrid, Padres Carmelitas Descalços, 2004, pp. 301-345.

\section{NOTAS}

1. Veja o desenvolvimento desde assunto em Sandra Costa Saldanha, A Basílica da Estrela: Real Fábrica do Santíssimo Coração de Jesus, Lisboa, Livros Horizonte, 2006 (no prelo).

2. Além de Santa Teresa de Ávila, esse programa inclui ainda as representações de Santo Elias, São João da Cruz e Santa Maria Madalena de Pazzi. 
3. Segundo Jesús Urrea, esta gravura terá servido de base à realização de uma escultura em barro, de artista anónimo, existente numa colecção particular da cidade de Valladolid. Jesús Urrea, Homenaje a Santa Teresa en el IV Centenario de su Muerte, Valladolid, Caja de Abonos Popular, 1982.

4. A estas obras juntam-se duas outras telas, cuja temática não cabe no programa decorativo inicial, com as representações de Nossa Senhora com o menino e Santo António e de São Filipe de Neri.

5. Cf. Sandra Costa Saldanha, op. cit.

6. Sobre Ana de Jesus veja-se artigo recentemente publicado por Maria del Puerto Alonso Fernández, "Ana de Jesús, profeta de ayer y hoy", Revista de Espiritualidad, vol. 63, Madrid, Padres Carmelitas Descalços, 2004, pp. 251-299.

7. Sobre Ana de São Bartolomeu veja-se Belén Yuste y Sonnia L. Rivas-Caballero, "Ana de San Bartolomé y la expansión del Carmelo Descalzo", Revista de Espiritualidad, vol. 63, Madrid, Padres Carmelitas Descalços, 2004, pp. 301-345.

8. A portada e as gravuras com os números $6-10,12,18,21$ e 23 não são assinadas; a número 2 é assinada por Galle; e as restantes por Collaert.

9. Biblioteca Nacional de Madrid, ER/1638. A edição de Ambers de 1613 foi publicada em facsímile por Carlos Sanz, Estampas de la vida de la Santa Madre Teresa de Jesús, Madrid, s. ed., 1962.

10. Adriaen Collaert, Cornelis Galle, Vila S. Virginis Teresiae a Iesu Ordinis Carmelitarum Excalceatorum piae restauratricis, Antuérpia, Apud Ioannem Galleum, 1630. Biblioteca Nacional de Lisboa, Secção de Iconografia, E.A. 14P, fls 138 - 162.

11. Vejam-se as diferenças apontadas entre as edições de 1613 e 1630 por Santiago Sebastián, Contrarreforma y Barroco: Lecturas iconográficas e iconológicas, $3^{\mathrm{a}}$ ed., Madrid, Alianza Editorial, 1989.

12. Sobre a influência exercida por esta obra na arquitectura carmelita veja-se o interessante texto de Dolores Garcia Hinajeros, "Las Ideas Arquitectonicas de Santa Teresa de Jesus", I Congreso Internacional del Monacato Femenino en España, Portugal y America - 1492-1992, vol. I, Leon, Universidade de Leon, 1993, p. 250.

13. Com as dimensões de $184 \times 220 \mathrm{~mm}$ em folha de $216 \times 252 \mathrm{~mm}$.

14. É, por exemplo, o caso das quatro telas existentes sob o retábulo-mór da igreja de Santa Teresa em Ávila, da autoria de Gregório Fernandez.

15. Biblioteca da Ajuda, 21-IX-11. Série referida por Luísa Arruda e Teresa Campos Coelho, Convento de S. Paulo da Serra de Ossa, Lisboa, Edições Inapa, 2004.

16. $2^{\mathrm{a}}$ edição, de 1669, existente na Konsinklijke Bibliotheek (Holanda).

17. Desta edição conhecem-se dois exemplares, respectivamente, na Biblioteca Municipal de Lyon, 811178 e na Mediateca Jean Jaurés, R 8-106. Em 1678 é publicada uma $2^{\mathrm{a}}$ edição da obra, revista aumentada e corrigida, da qual existe um exemplar na Biblioteca Nacional de Paris, 16-OC-3929.

18. BNM, ER/1619.

19. Sandra Costa Saldanha, op. cit.

20. José Meco, "A Divina Cintilação: talha, azulejos, mármores, chinoiseries", Convento dos Cardaes: Veio da Memória, Lisboa, Quetzal Editores, 2003, pp. 123, 125.

21. Painéis estudados por Fernando Ponce de León, "Os painéis de azulejo sobre Santa Teresa de Jesus, no convento de Santa Marta de Lisboa", Museu, IV série, n. 1, 1993, pp. 161-181.

22. Cuja azulejaria foi estudada por Luísa Arruda e Teresa Campos Coelho, op. cit.

23. Veja-se análise de Luís de Moura Sobral, "Josefa d'óbidos e as Gravuras: problemas de estilo e de iconografia", Josefa de óbidos e o tempo Barroco. Lisboa, T.L.P., 1991, pp. 51-69.

24. Localizados, respectivamente, na nave da igreja e no coro-alto. Com características compositivas e estilísticas diversas, foram elaborados em épocas distintas.

25. José Meco, op. cit.

26. Santa Teresa de Jesus, "Livro da Vida", Obras Completas, cap. I, ed., Oeiras, Edições Carmelo, 1994 , p. 5.

27. Idem, Ibidem, cap. IV, pp. 16-17. 
28. Idem, Ibidem, cap. IX, p. 61.

29. Idem, Ibidem, cap. XIII, pp. 88-90.

30. Idem, Ibidem, cap. XXIX, pp. 241-242.

31. Idem, Ibidem, cap. XXXI, p. 262.

32. Idem, Ibidem, cap. XXXIII, pp. 296-297.

33. Idem, Ibidem, cap. XXXIX, p. 362.

34. Santa Teresa de Jesus, "Fundações", Obras Completas, cap. I, $3^{\text {a }}$ ed., Oeiras, Edições Carmelo, 1994, pp. 1048-1051.

35. Santa Teresa de Jesus, "Livro da Vida", (...), pp. 350-356.

\section{RESUMOS}

O antigo convento do Santíssimo Coração de Jesus à Estrela encerra um interessante conjunto de painéis de azulejos alusivos à vida de Santa Teresa de Jesus, cujas composições foram concebidas a partir da cópia directa de dez gravuras do álbum Vita S. Virginis Teresiae a Iesv. Série biográfica impressa pela primeira vez em Amberes em 1613, a sua concretização coube aos célebres gravadores Adriaen Collaert e Cornelis Galle. Convertidas num modelo corrente para inúmeras obras de arte ao longo dos tempos, assumiram urna importância capital na fixação e desenvolvimento de parte da iconografia teresiana, constituindo-se como um eficaz veículo para a rápida difusão da sua biografia.

The old convent of the Holy Heart of Jesus in Lisbon has an interesting set of tile paneis, which compositions had been made directly from Vita S. Virginis Teresiae a Iesv album. Biographical series print in Ambers in 1613, the execution had been charged to the celebrated engravers Adriaen Collaert and Cornelis Galle. Converted in a common model for numerous works of art, they assumed a capital meaning in the development of theresian iconography.

ÍNDICE

Keywords: Basílica da Estrela, Saint Theresa of Ávila, carmelites, iconography, etching

Palavras-chave: Basílica da Estrela, Santa Teresa de Ávila, carmelitas, iconografia, gravura

\section{AUTOR}

\section{SANDRA COSTA SALDANHA}

Mestre em História da Arte e docente da Escola Superior de Design, tem publicado alguns estudos relativos à Arte e Iconografia Portuguesa dos séculos XVIII a XX, desenvolvendo actualmente um trabalho de investigação subordinado à Escultura Portuguesa do Século XIX. 